\title{
BUDOWANIE KONKURENCYJNOŚCI ORAZ ROZWÓJ RELACJI FIRM SEKTORA MŚP Z OTOCZENIEM SPOLECZNO-GOSPODARCZYM
}

\begin{abstract}
Wprowadzenie do przedsiębiorstwa koncepcji społecznej odpowiedzialności biznesu (CSR, Corporate Social Responsibility) jest szczególnie istotne w wypadku firm należących do sektora małych i średnich przedsiębiorstw (sektor MŚP). W sektorze MŚP w ostatnim czasie nastąpiła istotna zmiana sposobu prowadzenia biznesu. W systemie produkcyjnym wyróżnia się coraz więcej zadań o charakterze unikatowym, tak zwanych zleceń typu projekt. Sektor MŚP realizujący tego typu zlecenia jest szczególnie narażony na utratę konkurencyjności, gdyż zarządzanie projektami polega na zastosowaniu dużej wiedzy, doświadczeń, narzędzi, metod oraz technik w działaniach planistycznych w celu osiągnięcia lub przewyższenia potrzeb i oczekiwań zleceniodawców (kompetencje specjalistyczno-techniczne). Zakłada się, że w kontekście stosowania polityki CSR w przedsiębiorstwie, w tym w sektorze MŚP, istotną rolę odgrywać będą kompetencje menedżerskie, społeczne i osobowe. Z dotychczasowych badań i analiz wynika, że szczególnie małe i średnie przedsiębiorstwa potrzebują kompetentnych menedżerów projektów, którzy będą w stanie profesjonalnie zarządzać i kierować ich realizacją, stosując się jednocześnie do zasad polityki CSR. Dotychczasowe badania wskazują, że przedsiębiorstwa w sektorze MŚP zazwyczaj nie podejmują się przedsięwzięć polegających na analizie kompetencji: wiedzy, umiejętności oraz postaw i zachowań pracowników osiągających ponadprzeciętne rezultaty. Niewielu menedżerów projektów posługuje się odpowiednimi narzędziami i metodykami zarządzania projektami. Celem publikacji jest przedstawienie koncepcji badań dotyczących zbadania i analizy kompetencji menedżerskich, społecznych i osobowych kierowników projektów oraz zleceń typu projekt w kontekście obowiązujących zasad polityki CSR w sektorze MŚP. W pracy przedstawiono podstawowe przesłanki badań, sformułowano problem badawczy. Dokonano przeglądu stanu badań nad danym zagadnieniem oraz sformułowano cele, hipotezy oraz zadania, które wymagają realizacji.

Słowa kluczowe: społeczna odpowiedzialność biznesu, CSR, Corporate Social Responsibility, kompetencje, zlecenia typu projekt, przedsięwzięcie, projekt, sektor małych i średnich przedsiębiorstw, MŚP
\end{abstract}

\section{WPROWADZENIE}

Etyka biznesu i społeczna odpowiedzialność przedsiębiorstwa są wyzwaniem XXI wieku. Współczesne przedsiębiorstwa wykazują coraz większe zainteresowanie etycznym prowadzeniem działalności gospodarczej. W kontekście zrównoważonego rozwoju gospodarczego znaczenia nabiera koncepcja zarządzania przedsiębiorstwem zgodna z zasa-

\footnotetext{
${ }^{1}$ Dr inż. Iwona Pisz, Katedra Logistyki i Marketingu, Wydział Ekonomiczny, Uniwersytet Opolski, ul. Ozimska 46a, 45-058 Opole, e-mail: ipisz@uni.opole.pl, tel.: 774016898 (autor korespondencyjny).

${ }^{2}$ Dr inż. Iwona Łapuńka, Katedra Zarządzania Projektami, Instytut Inżynierii Produkcji i Logistyki, Wydział Inżynierii Produkcji i Logistyki, Politechnika Opolska, ul. Ozimska 75, 45-370 Opole, tel.: 7744988 50, e-mail: i.lapunka@po.opole.pl
} 
dami polityki społecznej odpowiedzialności biznesu (CSR, Corporate Social Responsibility) związanymi z normą ISO 26000. Jak wynika z badań coraz większa liczba przedsiębiorstw wdraża koncepcję społecznej odpowiedzialności biznesu do praktyki zarządzania $^{3}$.

Koncepcja społecznej odpowiedzialności biznesu powoli staje się standardem zarządzania przedsiębiorstw. Powinna być wdrażana nie tylko przez wielkie korporacje czy duże firmy. Coraz częściej zauważa się potrzebę jej stosowania również przez małe i średnie przedsiębiorstwa, które w znacznie większym stopniu przyczyniają się do rozwoju lokalnego otoczenia i społeczeństwa. Sektor małych i średnich przedsiębiorstw (sektor MŚP) jest zakorzeniony w swoich społecznościach lokalnych i kształtuje swój wizerunek poprzez stosowanie różnego rodzaju działań prospołecznych. Jednak nie zawsze właściciele oraz pracownicy sektora MŚP są świadomi wagi swoich działań i osiąganych rezultatów. Według autorów racjonalność podejmowania decyzji kadry menedżerskiej, w szczególności sektora małych i średnich przedsiębiorstw, jest jednym z kluczowych czynników powodzenia realizacji koncepcji CSR w przedsiębiorstwach, które mają istotny wpływ na konkurencyjność oraz rozwój relacji tego typu przedsiębiorstw z otoczeniem społeczno-gospodarczym. Celem publikacji jest przedstawienie koncepcji badań dotyczących zbadania i analizy kompetencji menedżerskich, społecznych i osobowych kierowników projektów (przedsięwzięć) oraz zleceń typu projekt w kontekście obowiązujących zasad polityki CSR w sektorze MŚP.

Mając to na uwadze, w dalszej części pracy przedstawiono ideę badań kompetencji menedżerskich, społecznych i osobowych kierowników projektów (przedsięwzięć) oraz zleceń typu projekt w kontekście obowiązujących zasad polityki CSR w kierunku podnoszenia konkurencyjności sektora małych i średnich przedsiębiorstw. Scharakteryzowano sektor małych i średnich przedsiębiorstw w kontekście realizacji unikatowych projektów (przedsięwzięć), które mogą być traktowane jako zlecenia typu projekt. Przedstawiono rownież dotychczasowy stan badań w ramach podjętego tematu. Zdefiniowano problem wymagający rozwiązania, wyłoniono główne cele oraz wynikające z nich zadania wymagające rozwiązania.

\section{ISTOTA SPOLECZNEJ ODPOWIEDZIALNOŚCI}

Koncepcja CSR jest oparta na zasadzie poszanowania interesów wszystkich podmiotów funkcjonujących w danym przedsiębiorstwie oraz jego otoczeniu. W pierwotnym ujęciu definiowane były podstawowe obowiązki przedsiębiorców wobec społeczeństwa. Zgodnie z definicją zaproponowaną przez Howarda R. Bowena koncepcja CSR oznacza obowiązek prowadzenia polityki, podejmowania decyzji oraz realizowania działań, które są zbieżne z oczekiwaniami społecznymi ${ }^{4}$. Według Światowej Rady ds. Zrównoważonego Rozwoju koncepcja CSR jest ciągłym zobowiązaniem biznesu do zachowań etycznych oraz do działań na rzecz rozwoju ekonomicznego przy jednoczesnej trosce o poprawę

\footnotetext{
${ }^{3}$ M. Bernatt, Spoleczna odpowiedzialność biznesu, Wymiar konstytucyjny i międzynarodowy, Wydawnictwo Naukowe Wydziału Zarządzania Uniwersytetu Warszawskiego, Warszawa 2009; Biznes, etyka, odpowiedzialność, red. W. Gasparski, PWN, Warszawa 2012; I. Ślęzak-Gładzik, Corporate Social Responsibility (CSR) jako koncepcja porządkująca relacje między biznesem a społeczeństwem, „Modern Management Review” XVIII/20 (2013), s. 113-125; http://biznes.pl/wiadomosci/raporty/spojnosc-i-mierzenie-efektywnoscikluczami-do-sukc,5607953,1,5585484,510,news-detal.html (dostęp: 10.03.2014).

${ }^{4}$ I. Ślęzak-Gładzik I., op. cit., s. 113-125.
} 
jakości życia pracowników i ich rodzin ${ }^{5}$. Koncepcja społecznej odpowiedzialności biznesu jest filozofią działania opartą na zasadzie poszanowania interesów wszystkich podmiotów funkcjonujących w danym przedsiębiorstwie, w tym pracowników oraz jego otoczeniu, może się ona odnosić również do łańcuchów dostaw, w ramach których funkcjonują określone podmioty gospodarcze ${ }^{6}$.

Rozpatrując wyzwania współczesnych przedsiębiorstw z perspektywy społecznie odpowiedzialnych oczekiwań, za szczególnie istotną należy uznać zdolność przedsiębiorców do spełnienia różnorodnych wymagań w zakresie respektowania interesów różnych grup interesariuszy ${ }^{7}$. Wynika to $\mathrm{z}$ teorii stakeholders, według której przedsiębiorstwo ma wielu interesariuszy, którzy stanowią klucz do osiągania określonych celów przedsiębiorstwa ${ }^{8}$.

W pierwotnym ujęciu koncepcja CSR wskazywała na obowiązki, jakie przedsiębiorcy mają wobec społeczeństwa. Obecnie coraz częściej CSR jest postrzegany jako element zarządzania danym przedsiębiorstwem. Przedsiębiorcy w swojej praktyce gospodarczej uwzględniają w swoich działaniach zarówno interesy społeczne, dobro środowiska naturalnego, jak i relacje $\mathrm{z}$ różnymi grupami interesariuszy. Według tego podejścia, bycie odpowiedzialnym nie oznacza tylko spełniania przez przedsiębiorstwa wszystkich wymogów formalnych i prawnych, ale oprócz tego również zwiększone inwestycje w zasoby ludzkie, w ochronę środowiska i relacje z interesariuszami, którzy mogą mieć faktyczny wpływ na efektywność działalności gospodarczej tych przedsiębiorstw, ich konkurencyjność oraz poziom innowacyjności. Zatem wydatki tego rodzaju należy traktować jako inwestycję i źródło innowacji, a nie jako koszt, podobnie jak w wypadku zarządzania jakością ${ }^{9}$.

W praktyce gospodarczej przedsiębiorstwa mają różne podejścia do społecznej odpowiedzialności. Wyróżnia się następujące podejścia do społecznej odpowiedzialności ${ }^{10}$ :

- opór;

- $\quad$ społeczny obowiązek;

- $\quad$ społeczna reakcja;

- $\quad$ społeczny wkład.

Na rysunku 1 przedstawiono stopniowe podejścia przedsiębiorstw do społecznej odpowiedzialności. Wynika z niego, że stopniowanie podejścia do społecznej odpowiedzialności zaczyna się od zupełnego oporu wobec działań podejmowanych na rzecz odpowiedzialności społecznej. To podejście jest zbieżne z poglądami oponentów koncepcji CSR.

\footnotetext{
${ }^{5}$ Ibidem, s. 115; M. Kaźmierczak, Bezpieczeństwo i higiena pracy a rozwój koncepcji społecznej odpowiedzialności biznesu, Zarządzanie i Ekonomia, 2009, nr. 5.

${ }^{6}$ A. Rudnicka, CSR - doskonalenie relacji społecznych w firmie, Wolters Kluwer, Warszawa 2012.

${ }^{7}$ K. Zięba, Poszerzenie obszaru stosowania koncepcji CSR - prezentacja praktyki postępowania w tym zakresie, „Organizacja i Zarządzanie” 2/22 (2013), s. 153-165.

${ }^{8}$ R.E. Freeman, Strategic Management: A stakeholders approach, Cambridge University Press, Cambridge 2010.

${ }^{9}$ I. Ślęzak-Gładzik, op. cit.,, s. 113-125.

${ }^{10}$ R.W. Griffin, Podstawy zarządzania organizacjami, PWN, Warszawa 1998.
} 


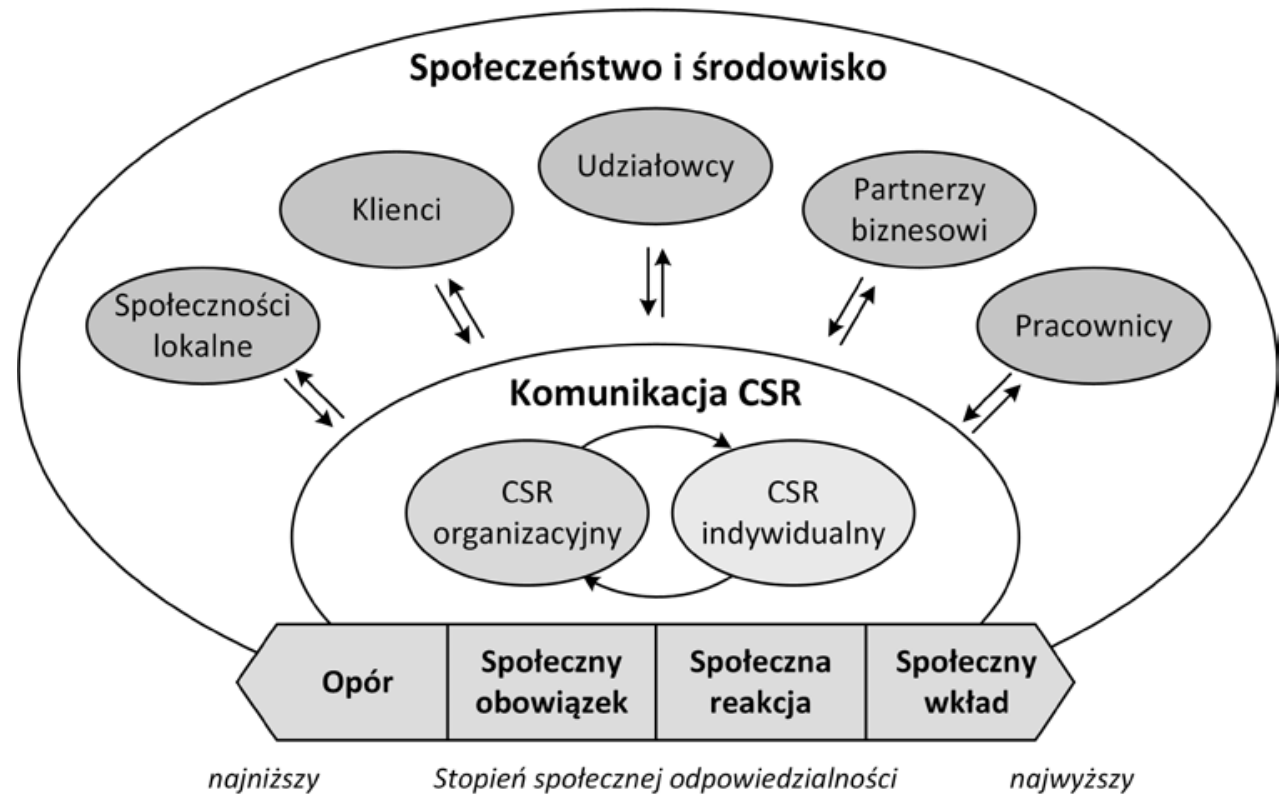

Rys. 1. Podejścia do społecznej odpowiedzialności

Źródło: opracowanie własne na podstawie R.W. Griffin, Podstawy zarządzania organizacjami, PWN, Warszawa 1998, s. 152.

Wśród oponentów tej koncepcji wymienić można Miltona Friedmana, który uważał, że odpowiedzialność społeczna spoczywa wyłącznie na jednostkach, odpowiedzialność przedsiębiorstwa zaś ogranicza się do zapewnienia zysku udziałowcom. Podkreślał on, że wyłącznym celem działania przedsiębiorcy jest maksymalizacja zysków w imię zobowiązań wobec swoich udziałowców ${ }^{11}$. Kolejny stopień społecznej odpowiedzialności stanowi społeczny obowiązek. Wynika z niego, że dane przedsiębiorstwo realizuje tylko te zadania, które wynikają z obowiązujących przepisów prawa, ale nic poza tym. Natomiast społeczna reakcja oznacza w praktyce, że dane przedsiębiorstwo wypełnia swoje podstawowe obowiązki prawne i etyczne, a w wybranych przypadkach wychodzi poza nie. Ostatnie podejście do społecznej odpowiedzialności jest najwyższym poziomem odpowiedzialności. W ramach społecznego wkładu dane przedsiębiorstwo identyfikuje się jako odpowiedzialny podmiot aktywnie poszukujący możliwości wniesienia swojego wkładu dla dobra społeczeństwa.

Należy podkreślić, że na etyczny kontekst przedsiębiorstwa składają się indywidualna etyka poszczególnych menedżerów oraz to, co wynika z praktyki danego przedsiębiorstwa. W wypadku przedsiębiorstw wdrażających koncepcję CSR istotnymi elementami wpływającymi na poziom społecznej odpowiedzialności są: kultura firmy, przywództwo,

${ }^{11}$ M. Friedman, Capitalism and Freedom, University of Chicago Press, Chicago 1962, s. 133-134, cyt. za: M. Bernatt, Społeczna odpowiedzialność biznesu. Wymiar konstytucyjny i międzynarodowy, Wydawnictwo Naukowe Wydziału Zarządzania Uniwersytetu Warszawskiego, Warszawa 2009. 
szkolenia, zbiór zasad, kodeksy postępowania, postawa oraz kompetencje pracowników, w tym kierowników projektów realizowanych przez przedsiębiorstwa. Jest to szczególnie istotne w wypadku małych i średnich przedsiębiorstw realizujących różnorodne zlecenia, w tym zlecenia typu projekt, projekty (przedsięwzięcia). W tym kontekście istotnego znaczenia nabiera opracowanie odpowiedniego modelu kompetencyjnego dla zespołów projektowych na czele z kierownikiem projektu w celu osiągnięcia zakładanego sukcesu podczas realizacji celów projektu (przedsięwzięcia), to znaczy celów, czyli kosztu - czasu - zakresu.

\section{STAN DOTYCHCZASOWYCH BADAŃ}

Z punktu widzenia podjętych badań na szczególną uwagę zasługuje sektor małych i średnich przedsiębiorstw (sektor MŚP) realizujący zlecenia typu projekt. W praktyce oznacza to realizację unikatowych zleceń wymagających indywidualnego podejścia, dużego nakładu czasu w proces przygotowania realizacji zlecenia. Sektor MŚP realizujący tego typu zlecenia jest w szczególności narażony na utratę konkurencyjności, gdyż zarządzanie projektami polega na zastosowaniu dużej wiedzy, doświadczeń, narzędzi, metod oraz technik w działaniach planistycznych w celu osiągnięcia lub przewyższenia potrzeb i oczekiwań zleceniodawców (kompetencje specjalistyczno-techniczne). Wiąże się to z koniecznością godzenia ze sobą wielu parametrów, takich jak czas, koszty, potrzeby i oczekiwania zleceniodawcy projektu, cele projektu ${ }^{12}$.

Małe i średnie przedsiębiorstwa stają się przedmiotem coraz głębszych rozważań zarówno teoretycznych, jak i praktycznych. Nauka o sektorze MŚP nie ma długiej tradycji. Badania zapoczątkowano w latach sześćdziesiątych ubiegłego wieku. Wprowadzono wówczas na rynek wydawniczy pierwsze periodyki dotyczące sektora MŚP: „Journal of Small Business Management”, „American Journal of Small Business”. W latach siedemdziesiątych XX w. wydano książkę E.F. Schumachera Small is Beautiful oraz ogłoszono Raport Komisji Boltona, odnoszący się między innymi do roli MŚP w gospodarce, problemów definicyjnych oraz ich charakterystyki. W latach dziewięćdziesiątych ubiegłego wieku międzynarodowe instytucje (między innymi Komisja Europejska, OECD) wzmogły badania nad stanem sektora MŚP. Obecnie prowadzone badania mają charakter epistemologiczny. Ich cele to poznanie tożsamości danego sektora, zebranie wiedzy oraz wyłonienie cech charakterystycznych dla danego sektora ${ }^{13}$.

\footnotetext{
12 B. Noteboom, Innovation and diffusion in small firm: theory and evidence, „Small Business Economics” 1994/6, s. 327-347; I. Pisz, I. Łapuńka, Zarzadzanie projektami w malych i średnich przedsiębiorstwach wyniki badań, „Gospodarka Materiałowa i Logistyka” 2012/7, s. 16-22; I. Pisz, I. Łapuńka, The idea of operationalization of the conceptual model of project driven orders for small and medium-sized enterprises in condition of uncertainty, [w:] Innovations in management and production engineering, red. R. Knosala, PTZP, Opole 2012, s. 297-308.

${ }^{13}$ J. Bogdanienko, Możliwości zwiększania innowacyjności małych $i$ średnich firm w warunkach globalnej konkurencji, „Problemy Zarządzania” 2007/4, s. 74-94; Commission European, Putting small businesses first Europe is good for SMEs, SMEs are good for Europe, European Commission Publications Office, Luxembourg 2008; K. Dziekoński, Zarzadzanie projektami w matych i średnich przedsiębiorstwach, „Ekonomia i Zarzadzanie” 2010/4, s. 97-104; D. Floyd, J. McManus, The role of SMEs in improving the competitive position of the European Union. „European Business Review” 7/2 (2005), s. 144-150; A. Kurczewska, Dyskusja nad pojęciem małego i średniego przedsiębiorstwa, Obecność problematyki sektora MSP w nauce ekonomii, „Ekonomista” 2009/2, s. 259-272; Zeszyty naukowe nr 752, Uwarunkowania rynkowe rozwoju mikro, malych i średnich przedsiębiorstw. Mikrofirma 2013, „Ekonomiczne problemy usług” 2013/102.
} 
Szczególnego znaczenia nabierają badania dotyczące wdrożenia zarządzania projektem do praktyki przedsiębiorstw, szczególnie małych i średnich. Badania nad stanem zarządzania projektami sektora MŚP prowadzili między innymi Turner i jego zespół14, Owens ${ }^{15}$, Dziekoński ${ }^{16}$, Żmigrodzki ${ }^{17}$, Pisz, Łapuńka ${ }^{18}$. Z przeprowadzonych przez nich badań wynika, że małe i średnie przedsiębiorstwa zmuszone są do samodzielnego radzenia sobie podczas realizacji zleceń typu projekt i przeważnie przypomina to raczej działania ad hoc niż usystematyzowany zbiór metod stanowiący spójne pojęciowo podejście do zarządzania projektem czy chociażby zbiór zasad dotyczących sposobów wykonywania jakiejś pracy lub trybu postępowania prowadzącego do określonego celu. Większość ankietowanych przedsiębiorstw w tych badaniach nie stosuje żadnych standardów, technik, narzędzi zarządzania projektami. Struktury organizacyjne oraz wyróżnione role wynikające $\mathrm{z}$ realizacji podejmowanych projektów, jeżeli w ogóle występują, nie są jasno określone. Do głównych problemów zarządzania projektami w MŚP zaliczono: rosnące koszty projektów w trakcie realizacji, zmienność popytu, opóźnienia realizacji projektów, konflikty w grupie projektowej, dużą liczbę reklamacji.

Ostatnio w zarządzaniu projektami można zaobserwować bardzo szeroką popularyzację tak zwanych modeli kompetencji zarządzania projektami lub modeli kompetencji kierowników projektów. Organizacjami odpowiedzialnymi za ich powstanie i rozwój są zazwyczaj fachowe stowarzyszenia, między innymi International Project Management Association (IPMA Competency Baseline), Project Management Institute (Project Manager Competency Development Framework), Engineering Construction Industry Training Board (National Occupational Standards for Project Management), Australian Institute for Project Management (Professional Competency Standards for Project Management) ${ }^{19}$.

Z punktu widzenia światowych standardów opracowane modele wskazują zakres kompleksowych i szczegółowych wytycznych definiujących elementy oraz poziomy kompetencji pożądane i wymagane od pracowników pełniących określone funkcje i stanowiska. Praktyka zarządzania projektami w małych i średnich przedsiębiorstwach jest jednak zupełnie różna od opracowanych standardów. Zdaniem R. Newtona bardzo duże znaczenie dla sukcesu realizacji projektu przypisuje się samemu menedżerowi projektu, $\mathrm{w}$ szczególności jego wiedzy i kompetencjom, przejawiającym się w umiejętności wydoby-

\footnotetext{
${ }^{14}$ J.R. Turner, A. Ledwith, J. Kelly, Project management in small to medium-sized enterprises. A comparison between firms by size and industry, „International Journal of Managing Projects in Business” 2/2 (2009), s. 282-296; J.R. Turner, A. Ledwith, J. Kelly, Project management in small to medium-sized enterprises: Matching processes to nature of the firm, „International Journal of Project Management” 2010/28, s. 744-755.

${ }^{15}$ J.D. Owens, Why do some UK SMEs still find the implementation of a new product development process problematic? An explanatory investigation, „Management Decision” 45/2 (2006), s. 235-251.

${ }^{16} \mathrm{~K}$. Dziekoński, Zarzadzanie projektami w matych i średnich przedsiębiorstwach, „Ekonomia i Zarządzanie” 2010/4, s. 97-104.

${ }^{17}$ M. Żmigrodzki, Zarządzanie portfelem projektów matymi kroczkami, www.octigo.pl (dostęp: 23.04.2012).

${ }^{18}$ I. Pisz, I. Łapuńka, Zarządzanie projektami w matych i średnich przedsiębiorstwach - wyniki badań, „Gospodarka Materiałowa i Logistyka” 2012/7, s. 16-22; I. Pisz, I. Łapuńka, The idea of operationalization of the conceptual model of project driven orders for small and medium-sized enterprises in condition of uncertainty, [w:] Innovations in management and production engineering, red. R. Knosala, PTZP, Opole 2012, s. 297-308.

${ }^{19}$ A. Musiał-Urbańczyk, Kompetencje kierownika projektu i możliwości ich kształtowania, Wydawnictwo Politechniki Śląskiej, Gliwice 2010; R. Newton, The project manager: mastering the art of delivery, Pearson Education Limited, Harlow 2005; R. Woloński, Rola wiedzy i innowacji w rozwoju matych $i$ średnich przedsiebiorstw - przeglad dotychczasowych badań, „Problemy zarządzania” 2007/4, s. 128-155; P. Wyrozębski, Modele kompetencji w zarzadzaniu projektami, „e-mentor” 2009/2.
} 
wania najlepszych elementów z pracy zespołowej oraz zorientowaniu na jakość ${ }^{20}$. Aktualnie coraz bardziej rozpowszechnia się przekonanie, że to właśnie ludzie są kluczem do sukcesu w realizacji projektów ${ }^{21}$. Podziela tę opinię Z. Wong, twierdząc, że czynnik ludzki ma bardzo istotne znaczenie, kształtowanie głównych procesów w projektach zależy bowiem w dużym stopniu od wiedzy i umiejętności pracowników, a przede wszystkim od zachowań organizacyjnych i przyjmowanych postaw ${ }^{22}$. Istotne są również zorientowanie na cele ${ }^{23}$ oraz umiejętność zarządzania zmianami, ponieważ każdy projekt, jako unikatowe przedsięwzięcie organizacyjne, w rezultacie prowadzi do zmian ${ }^{24}$.

$\mathrm{W}$ istocie sprawne zarządzanie, trafne podejmowanie decyzji, umiejętne sterowanie realizacją projektu, jak również pozostałe kompetencje biznesowe oraz umiejętności behawioralne $\mathrm{i}$ interpersonalne będą niebywale pożądanymi cechami każdego menedżera projektu. Cechy te stanowią jeden z kluczowych czynników sukcesu projektu, co w konsekwencji przekłada się na wyniki prowadzonej działalności przedsiębiorstwa w postaci zysków z realizowanych przez przedsiębiorców projektów na wzrost konkurencyjności na rynku towarów i usług ${ }^{25}$.

Powszechnie zakłada się, że kompetencje menedżerów projektów powinny być ukierunkowane na sukces projektu, czyli osiągnięcie zakładanego celu nadrzędnego, w zaplanowanym czasie, w ramach założonych kosztów, odpowiadającego zakładanym parametrom jakościowym projektu. W dobie globalizacji zauważalna jest ewolucja modeli zarządzania $\mathrm{w}$ podejściu projektowym od modelu procesu wewnętrznego, poprzez model stosunków międzyludzkich, aż do modelu otwartych systemów. Zmienna jest rola menedżera projektu adekwatnie do modelu: monitorujący-koordynator, mentor-moderator, innowator-pośrednik. W odpowiedzi na te zmiany szczególnie należy doprecyzować wartości, którymi powinna kierować się kadra menedżerska projektów w ramach społecznej odpowiedzialności, takich jak: ład organizacyjny, prawa człowieka, stosunki pracy, środowisko, sprawiedliwe praktyki rynkowe, relacje $\mathrm{z}$ konsumentami oraz zaangażowanie społeczne.

Zakłada się, że w kontekście stosowania polityki CSR istotną rolę odgrywać będą kompetencje menedżerskie, społeczne i osobowe. Kompetencje nie są cechami stałymi. Zmieniają się wraz z doświadczeniem oraz rozwojem zawodowym i życiowym człowieka. Nie ma więc możliwości określenia raz na zawsze, czy ktoś daną kompetencję ma lub nie. Sam pomiar kompetencji jest złożonym procesem, ale większość teoretyków zgadza się z tym, że obiektywnie można tego dokonać jedynie na podstawie zbioru obserwowal-

${ }^{20} \mathrm{~K}$. Dziekoński, Zarzadzanie projektami w matych i średnich przedsiębiorstwach, „Ekonomia i Zarządzanie” 2010/4, s. 97-104.

${ }^{21}$ F. Acedo, J. Florin, An entrepreneurial cognition perspective on the internationalization of SMEs, „Journal of International Entrepreneurship" 4/1 (2006), s. 49-67; Z. Wong, Human factors in project management, Jossey-Bass, San Francisco 2007.

${ }^{22}$ A. Musiał-Urbańczyk, Kompetencje kierownika projektu i możliwości ich kształtowania, Wydawnictwo Politechniki Śląskiej, Gliwice 2010.

${ }^{23}$ A. Murphy, A. Ledwith, Project management tools and techniques in high-technology SMEs, „Management Research News” 30/2 (2007), s. 153-166.

${ }^{24}$ J. Brilman, Nowoczesne koncepcje i metody zarzadzania, PWE, Warszawa 2002; J. Clements, J. Gido, Successful project management, Cengage Learning, Mason 2009; A. Hamilton, Managing project for success, Thomas Telford Ltd., London 2001; J.M. Nicholas, H. Steyn, Zarzadzanie projektami, Wolters Kluwer Polska, Warszawa 2012

${ }^{25}$ P. Wyrozębski, Modele kompetencji w zarządzaniu projektami, „e-mentor” 2009/2.. 
nych zachowań. Znaczenie kompetencji zespołu projektowego, a w szczególności menedżera, dla sukcesu projektu jest powszechnie znane i nie ulega wątpliwości ${ }^{26}$. Wiedza i kompetencje poszczególnych osób powinny decydować o ich przynależności do zespołu i pełnionej w nim funkcji, niemniej jednak proces doboru i rekrutacji odpowiednich osób w celu współpracy często leży poza zakresem oddziaływania menedżera projektu, a przy tym on sam nie wykazuje odpowiednich kompetencji.

Brak odpowiednich kompetencji (wiedzy, umiejętności i postaw) członków zespołów projektowych, w tym menedżerów projektów realizowanych przez sektor MŚP, powoduje istotne konsekwencje w osiągnięciu (lub nie) celu projektu w określonym czasie, w ramach założonych kosztów i przy zachowaniu wymaganej jakości. Głównym wnioskiem płynącym z dotychczasowych obserwacji i analiz jest fakt, że szczególnie małe i średnie przedsiębiorstwa potrzebują kompetentnych menedżerów projektów, którzy będą w stanie profesjonalnie zarządzać i kierować ich realizacją: wprowadzać zmiany organizacyjne i nowe technologie, wdrażać strategiczne projekty rozwojowe czy oddawać do użytku obiekty budowlane - na czas, zgodnie z budżetem oraz z wymaganiami jakościowymi, stosując się jednocześnie do zasad polityki CSR.

\section{SFORMULOWANIE PROBLEMU}

Wprowadzenie do przedsiębiorstwa podejścia do zarządzania projektami, szczególnie istotne jest w wypadku przedsiębiorstw należących do sektora małych i średnich przedsiębiorstw MŚP. Przedsiębiorstwa tego typu są wrażliwe na zmiany na rynku towarów i usług. Dodatkowo są narażone one na turbulencje, które wynikają z kryzysu gospodarczego $^{27}$. Zmiana sposobu prowadzenia biznesu, wyróżnianie w systemie produkcyjnym zadań o charakterze rutynowym oraz zadań o charakterze unikatowym, tak zwanych projektów, wydaje się koniecznością. Podejście procesowe, jak i podejście projektowe są istotne $\mathrm{z}$ punktu widzenia utrzymania pozycji na rynku danego przedsiębiorstwa ${ }^{28}$.

Zamiana inicjatywy projektu w materialne rezultaty, tworzące wartość dla organizacji wśród przedsiębiorstw zaliczanych do sektora MŚP, odbywa się chaotycznie, zasadniczo odbiega od przyjętych na wstępie realizacji projektu planów bazowych, nie ma wdrożonych metodyk zarządzania projektami i przeważnie przypomina to raczej działania po-

\footnotetext{
${ }^{26}$ Spałek S., Krytyczne czynniki sukcesu w zarządzaniu projektami, Wydawnictwo Politechniki Śląskiej, Gliwice 2004.

${ }^{27}$ D. Low, R. Chapman, Inter-relationships between innovation and market orientation of SMEs, „Management Research News” 30/12 (2007), s. 878-891; Raport o stanie sektora matych $i$ średnich przedsiebiorstw $w$ Polsce w latach 2007-2008, red. A. Żołnierski, Polska Agencja Rozwoju Przedsiębiorczości, Warszawa 2009; Raport o stanie sektora matych i średnich przedsiębiorstw w Polsce, red. A. Brussa, A. Tarnawa, Polska Agencja Rozwoju Przedsiębiorczości, Warszawa 2011; C. Salvato, U. Lassini, J. Wiklun, Dynamics of external growth in SMEs: Process of model acquisition capabilities emergence, „Schmalebach Business Review” 59/3 (2007), s. 282-305.

${ }^{28}$ A. Hamilton, Managing project for success, Thomas Telford Ltd., London 2001; M. Kaźmierczak, Bezpieczeństwo $i$ higiena pracy a rozwój koncepcji spolecznej odpowiedzialności biznesu, „Zarządzanie i Ekonomia”, 2009/5; A.A. Szpitter, Innowacyjne podejście do zarządzania projektami, „Przegląd organizacji” 2012/1, s. 10-13; G. Von Dran, L. Kappelman, V. Prybutok, Empowerment and the management of an organizational transformation project, „Project Management Journal” 27/1 (1996), s. 12-17; W. Walczak Orientacja na cele w zarządzaniu projektami, „Master of Business Administration” 2009/4, s. 46-55.
} 
dejmowane doraźnie niż usystematyzowany zbiór metod stanowiący spójne pojęciowo podejście do zarządzania projektem ${ }^{29}$.

Transformacja produkcji na zlecenie w podejście projektowe (zlecenie typu projekt) wymaga zastosowania dużej wiedzy, doświadczeń, narzędzi, nowych metod oraz technik w celu osiągnięcia lub przewyższenia potrzeb i oczekiwań zleceniodawców (kompetencje specjalistyczno-techniczne menedżera i zespołu projektowego). Z kolei zakłada się, że w kontekście stosowania polityki CSR istotną rolę odgrywać będą kompetencje menedżerskie, społeczne i osobowe. Sam pomiar kompetencji jest złożonym procesem, ale większość teoretyków zgadza się z tym, że obiektywnie można tego dokonać jedynie na podstawie zbioru obserwowalnych zachowań. Znaczenie kompetencji zespołu projektowego, a w szczególności menedżera, dla sukcesu projektu jest powszechnie znane i nie ulega wątpliwości ${ }^{30}$.

Rozwiązanie problemu sprowadza się do znalezienia odpowiedzi na następujące pytania:

1. Jaki jest poziom skuteczności zarządzania projektami w sektorze MŚP w Polsce? Jakie przesłanki i ograniczenia warunkują wykorzystanie zarządzania projektami w sektorze MŚP w Polsce?

2. Czy powołane $\mathrm{w}$ małych $\mathrm{i}$ średnich przedsiębiorstwach zespoły projektowe są w stanie sprostać wymaganiom związanym z profesjonalną realizacją projektu?

3. Czy menedżerowie projektów mają odpowiedni zestaw kompetencji: wiedza z danego zakresu (wiem co), umiejętności (wiedza proceduralna - wiem jak i potrafię), postawy (chcę i jestem gotów wykorzystać swą wiedzę)?

4. Czy menedżerowie projektów dysponują odpowiednimi cechami osobowości, aby podołać oczekiwaniom członków zespołu, jak również pozostałych interesariuszy projektu (sponsor, wykonawca, użytkownik)?

5. Kim jest menedżer projektu w polskim sektorze MŚP? Jakie są jego zadania, jakie pełni funkcje, czym różni się od menedżerów dużych korporacji/przedsiębiorstw? Czy można wyróżnić cechy charakterystyczne menedżera, specyficzne dla funkcjonowania różnych branż na rynku?

6. Jak menedżerowie projektów definiują efektywność? Jakie umiejętności/wykształcenie trzeba posiadać, aby móc być efektywnym menedżerem projektu (pojęcie efektywności w rozumieniu otoczenia sektora MŚP)?

7. Jak można zostać menedżerem projektu w sektorze MŚP? Jakie są główne ścieżki kariery?

8. Jakie czynniki wpływają na rozwój profesji menedżera projektu w polskim sektorze MŚP? Jaka jest przyszłość zawodu menedżera projektu w sektorze MŚP w Polsce?

9. Jak kultura organizacji wpływa na zadania i role podejmowane przez poszczególnych menedżerów projektu w odniesieniu do obowiązujących zasad polityki CSR? Jak zróżnicowanie kulturowe poszczególnych organizacji wpływa na możliwości spójnego zarządzania projektem i na możliwość transferu wiedzy i kadry zarządczej pomiędzy organizacjami?

10. Jakie czynniki wspierają, a jakie hamują prorynkowe zmiany w badanym sektorze w odniesieniu do obowiązujących zasad polityki CSR?

\footnotetext{
${ }^{29}$ D. Floyd, J. McManus, The role of SMEs in improving the competitive position of the European Union, „European Business Review" 7/2 (2005), s. 144-150.

${ }^{30}$ M. Kaźmierczak, Bezpieczeństwo i higiena pracy a rozwój koncepcji społecznej odpowiedzialności biznesu, „Zarządzanie i Ekonomia” 2009/5.
} 


\section{ISTOTA BADAŃ}

Podejmowany przez autorów problem jest konsekwencją zmian na rynku towarów i usług oraz zmiany myślenia i działania przedsiębiorstw. W niniejszym rozdziale przedstawiono przesłanki podjęcia badań kompetencji kierowników projektów (przedsięwzięć) oraz zleceń typu projekt w kontekście obowiązujących zasad koncepcji CSR:

- wzrost zainteresowania zarówno badaczy, jak i przedsiębiorców zarządzaniem projektami,

- zmiany na rynku towarów i usług - indywidualizacja produktów i usług,

- transformacja produkcji na zapas na produkcję na zlecenie,

- permanentne zmiany wewnątrz przedsiębiorstwa oraz dynamika otoczenia przekładają się na wzrost zapotrzebowania na działania o charakterze unikatowym i jednorazowym,

- rozwój sektora MŚP jest motorem napędowym gospodarki zarówno krajowej, jak i europejskiej,

- małe i średnie przedsiębiorstwa realizują większą liczbę projektów niż kilkanaście lat temu,

- potrzeba szybkiej weryfikacji szans i zagrożeń płynących z podjęcia się przez przedsiębiorcę sektora MŚP zlecenia,

- potrzeba zwiększenia konkurencyjności sektora MŚP,

- wyniki badań wskazują, że znaczna część prowadzonych projektów w przedsiębiorstwach kończy się niepowodzeniem,

- poziom efektywności i skuteczności realizacji projektów zależy od ukształtowania systemu zarządzania projektami,

- powstawanie nowych i zmiana starych ról wyodrębnionych w wyniku społecznego podziału pracy w Polsce oraz powiązana $\mathrm{z}$ tym tendencja do profesjonalizacji zarządzania podmiotami gospodarczymi,

- $\quad$ spośród sześciu głównych czynników, wpływających na powodzenie projektu aż trzy - zidentyfikowane jako najważniejsze - dotyczą bezpośrednio roli menedżera projektu $^{31}$,

- dzięki odpowiedzialności społecznej, małe i średnie przedsiębiorstwa mogą poprawić swoją reputację, a tym samym zwiększyć zyski,

- wprowadzenie problematyki ochrony środowiska i polityki społecznej do strategii przedsiębiorstwa pozwala obniżyć koszty (opłaty za energię, wodę, opłaty z tytułu zanieczyszczeń) i zapewnia lepszą odporność na kryzysy, zwiększając zaufanie interesariuszy,

- małe i średnie przedsiębiorstwa o rozwiniętej strategii w zakresie odpowiedzialności społecznej łatwiej przywiązują wartościowych pracowników, lepiej motywują swoich pracowników i przyciągają młode talenty,

- rosnące znaczenie gospodarcze i społeczne koncepcji CSR przede wszystkim

w Polsce, ale też w kontekście europejskim i światowym,

- niedostatek badań empirycznych w zakresie CSR w polskim kontekście.

\footnotetext{
${ }^{31}$ S. Spałek, Krytyczne czynniki sukcesu w zarzadzaniu projektami, Wydawnictwo Politechniki Śląskiej, Gliwice 2004.
} 
Analiza i ocena wpływu podejścia projektowego na postawy, preferencje oraz zachowania komunikacyjne kadry menedżerskiej podmiotów gospodarczych należących do sektora MŚP pod względem podejmowania racjonalnych decyzji z punktu widzenia społecznej odpowiedzialności biznesu są autorskim pomysłem badania. Obszary wartości, którymi powinna się kierować kadra menedżerska sektora MŚP w ramach społecznej odpowiedzialności biznesu, nie zostały dotychczas rozpoznane. Należy podkreślić, że według autorów odgrywają one niebagatelną rolę zarówno w naukach o zarządzaniu, jak i gospodarce narodowej. Przedstawione działania mają charakter unikatowy, noszą znamiona innowacyjności. Opracowanie kryteriów oceny oraz narzędzi umożliwiających ocenę wpływu podejścia projektowego w badanych przedsiębiorstwach stanowią innowacyjny element badań. Zdefiniowanie czynników mających wpływ na postawy, preferencje oraz zachowania kadry menedżerskiej sektora MŚP z punktu widzenia społecznej odpowiedzialności biznesu jest istotnym zadaniem wyłonionym do realizacji w ramach podjętego tematu badań. Opracowanie rekomendacji innowacyjnych rozwiązań dla jej kluczowych obszarów, takich jak: ład organizacyjny, prawa człowieka, stosunki pracy oraz relacje z konsumentami, stanowi wymierny efekt badań. Stałe doskonalenie zarządzania przedsiębiorstwem w podejściu projektowym, szczególnie w kontekście spełnienia zasad polityki CSR wynikających z normy ISO 26000, jest niezbędnym elementem przewagi konkurencyjnej na współczesnym rynku. Wnioski z przeprowadzonych badań w wybranych przedsiębiorstwach sektora MŚP w Polsce pozwolą uchwycić i zobrazować schemat procesu zachodzących zmian $\mathrm{w}$ tym zakresie.

Celem pośrednim prowadzonych badań jest eksploracja i opis wybranego obszaru badawczego, czyli zmieniającej się profesji menedżerów projektów w polskim sektorze MŚP z punktu widzenia obowiązujących zasad polityki CSR. Główną przesłanką do podjęcia badań jest więc $\mathrm{z}$ jednej strony zaspokojenie ciekawości i lepsze zrozumienie eksplorowanej roli menedżerów, z drugiej sprawdzenie możliwości zaprojektowania szerszych badań oraz wypracowanie narzędzi, które mogłyby zostać w nich użyte. Konieczne jest uporządkowanie różnorodności ról i zadań poprzez zaproponowanie kategoryzacji i szczegółowy opis specyfiki poszczególnych grup menedżerów projektów. Bez zaproponowania podstawowych kategorii i pojęć, bez generalnego zarysu tworzącej się profesji, trudno przeprowadzić bardziej szczegółowe badania.

Opisując obszar badawczy, należy się skoncentrować na uchwyceniu dynamiki i mechanizmów zmian zachodzących w obszarze zarządzania projektem. W związku z tym, że dziedzina ta szybko się rozwija, szczególną uwagę przypisuje się zmieniającym się wzorcom ról menedżera projektu. W tym wypadku niemożliwe jest abstrahowanie od szerszego kontekstu, w tym kulturowego, organizacji i jego wpływu na perspektywy i kierunki dalszych zmian. Niewątpliwie interesujące i warte uwagi jest uchwycenie procesu tych przeobrażeń $\mathrm{w}$ ramach profesji menedżera projektu.

Reasumując, główne cele poznawcze podjętych badań są następujące:

- szczegółowe opisanie zawodu menedżerów projektów w polskim sektorze MŚP,

- skategoryzowanie różnorodności profesjonalnych ról funkcjonujących w obszarze zarządzania projektem,

- uchwycenie uwarunkowań i dynamiki profesjonalizacji kadr zarządczych w Polsce przy uwzględnieniu szerszego kontekstu (zarówno kulturowego, jak i wpływu sytuacji sektora MŚP w świecie). 
Wyróżnione cele praktyczne prowadzonych badań obejmują między innymi:

- przybliżenie charakterystyki różnych ról menedżerów projektów osobom potencjalnie zainteresowanym taką karierą zawodową oraz tym, którzy chcieliby zrozumieć specyfikę funkcjonowania sektora MŚP od strony organizacyjnej,

- ułatwienie procesu dydaktycznego kadr zarządczych do wdrożenia zasad polityki CSR dla sektora MŚP poprzez wzbogacenie bazy wiedzy.

Sformułowanie problemu oraz celów badań pozwala na postawienie hipotez badawczych. W badaniu wyłoniono następujące hipotezy badawcze:

H1. Zarządzanie projektami w polskim sektorze MŚP charakteryzuje się niskim poziomem skuteczności.

H2. Menedżerowie projektów w polskim sektorze MŚP to niejednorodna grupa z punktu widzenia zadań, ról i codziennych obowiązków.

H3. Możliwe jest stworzenie kategoryzacji menedżerów projektów sektora MŚP, w ramach której poszczególne kategorie będą w określonych płaszczyznach homogeniczne.

H4. Różnice w kulturach poszczególnych małych i średnich przedsiębiorstw w Polsce mają istotne znaczenie dla zróżnicowania zadań i ról menedżerów projektów.

H5. Możliwe jest uchwycenie mechanizmów zmian na etapie intensywnego kształtowania i redefiniowania zawodu menedżera projektu w sektorze MŚP.

H6. W małych i średnich przedsiębiorstwach istnieje znikoma wiedza na temat zasad polityki CSR, sektor MŚP nie ma doświadczenia w kierowaniu programami społecznymi.

H7. Sektor MŚP w Polsce charakteryzuje się niewystarczającym poziomem wartości w ramach społecznej odpowiedzialności, takich jak: ład organizacyjny, prawa człowieka, stosunki pracy, środowisko, sprawiedliwe praktyki rynkowe, relacje z konsumentami oraz zaangażowanie społeczne.

Wybrana metodyka badań pozwoli na uzyskanie wyczerpujących odpowiedzi na postawione pytania, a także na zweryfikowanie hipotez badawczych.

Wyniki badań empirycznych pozwolą uchwycić kontekst cech kadry menedżerskiej zespołów projektowych w polskim sektorze MŚP $\mathrm{w}$ odniesieniu do decyzji racjonalnych z punktu widzenia podejścia projektowego i ukierunkowany na wybrane zasady polityki CSR, takie jak: ład organizacyjny, prawa człowieka, stosunki pracy oraz relacje z konsumentami. Zaproponowane na ich podstawie rekomendacje dla osób zarządzających projektami w małych i średnich przedsiębiorstwach, ale także dla wszystkich tych, którzy W swojej pracy mają do czynienia $\mathrm{z}$ tego typu przedsięwzięciami, stanowić będzie zbiór zaobserwowanych prawidłowości o charakterze aplikacyjnym.

W celu właściwej realizacji podjętego tematu badań wyróżniono wiele zadań. W tabeli 1 przedstawiono główne zadania, które umożliwią realizację ustalonych celów badań. W ramach badań wyróżniono zakres badań przedmiotowy, który stanowią kompetencje menedżerskie, społeczne i osobowe kierowników projektów w kontekście obowiązujących zasad polityki CSR. Zakres podmiotowy badań obejmuje co najmniej 100 funkcjonujących na rynku małych i średnich przedsiębiorstw w Polsce (zaliczanych do sektora MŚP). Badania prowadzone będą na obszarze Rzeczypospolitej Polskiej. W dalszej perspektywie przewiduje się badania na obszarze Unii Europejskiej w celu porównania wyników badań. 
Tabela 1. Zadania wyłonione do realizacji w ramach badań

\begin{tabular}{|c|c|}
\hline Lp. & Zadania \\
\hline 1. & $\begin{array}{l}\text { Badanie stanu aktualnego sposobu planowania i realizacji projektów przez } \\
\text { menedżerów sektora MŚP w Polsce }\end{array}$ \\
\hline 2. & $\begin{array}{l}\text { Badanie kompetencji technicznych menedżerów projektów w zakresie } \\
\text { zarządzania projektami sektora MŚP w Polsce }\end{array}$ \\
\hline 3. & $\begin{array}{l}\text { Badanie postaw, preferencji i kompetencji (menedżerskich, społecznych, } \\
\text { osobowych) menedżerów projektów sektora MŚP w Polsce }\end{array}$ \\
\hline 4. & Opracowanie i statystyczna analiza wyników badań \\
\hline 5. & $\begin{array}{l}\text { Ocena skuteczności zarządzania projektami sektora MŚP w Polsce. Ocena } \\
\text { wpływu podejścia projektowego na zachowanie kierowników projektów. } \\
\text { Sformułowanie wstępnych wniosków }\end{array}$ \\
\hline 6. & $\begin{array}{l}\text { Badania na podstawie próby eksperckiej w zakresie wpływu podejścia } \\
\text { projektowego na postawy, preferencje oraz zachowanie komunikacyjne } \\
\text { menedżerów projektów sektora MŚP w Polsce w kontekście społecznej } \\
\text { odpowiedzialności biznesu }\end{array}$ \\
\hline 7. & $\begin{array}{l}\text { Ocena spójności decyzji podejmowanych przez menedżerów projektów } \\
\text { sektora MŚP w Polsce w ramach realizacji projektów w aspekcie społecz- } \\
\text { nej odpowiedzialności biznesu }\end{array}$ \\
\hline 8. & Prezentacja i ocena wyników badań \\
\hline 9. & $\begin{array}{l}\text { Weryfikacja wstępnie przyjętych założeń odnośnie do oceny skuteczności } \\
\text { zarządzania projektami w sektorze MŚP w Polsce w kontekście społecznej } \\
\text { odpowiedzialności biznesu }\end{array}$ \\
\hline 10. & $\begin{array}{l}\text { Opracowanie założeń kategoryzacji menedżerów projektów sektora MŚP } \\
\text { w Polsce w ramach wyszczególnionych obszarów społecznej odpowie- } \\
\text { dzialności biznesu, takich jak: ład organizacyjny, prawa człowieka, sto- } \\
\text { sunki pracy oraz relacje z konsumentami }\end{array}$ \\
\hline 11. & $\begin{array}{l}\text { Rekomendacja oraz opracowanie szkoleń dla kadry menedżerskiej sektora } \\
\text { MŚP w Polsce w zakresie wartości, jakimi powinni się kierować w spo- } \\
\text { łecznej odpowiedzialności biznesu }\end{array}$ \\
\hline 12. & Podsumowanie badań. Promocja badań \\
\hline
\end{tabular}

\section{PODSUMOWANIE}

Znaczenie kompetencji zespołu projektowego, a w szczególności menedżera, dla sukcesu projektu jest powszechnie znane i nie ulega wątpliwości. Wiedza i kompetencje poszczególnych osób powinny decydować o ich przynależności do zespołu i odgrywanej w nim roli, niemniej jednak proces doboru i rekrutacji odpowiednich osób w celu współpracy często leży poza zakresem oddziaływania menedżera projektu, a przy tym on sam nie wykazuje odpowiednich kompetencji. 
Sprawne zarządzanie, trafne podejmowanie decyzji, umiejętne sterowanie realizacją projektu, jak również pozostałe kompetencje biznesowe oraz umiejętności behawioralne $\mathrm{i}$ interpersonalne są niebywale pożądanymi cechami każdego menedżera projektu. Cechy te stanowią jeden z kluczowych czynników sukcesu projektu, co w konsekwencji powoduje przełożenie wyników prowadzonej działalności przedsiębiorstwa w postaci zysków z realizowanych przez przedsiębiorców projektów na wzrost konkurencyjności na rynku towarów i usług.

Z dotychczasowych badań i analiz wynika, że szczególnie małe i średnie przedsiębiorstwa potrzebują kompetentnych menedżerów projektów, którzy będą w stanie profesjonalnie zarządzać i kierować ich realizacją, stosując się jednocześnie do zasad polityki CSR. Dotychczasowe badania jednoznacznie wskazują, że współczesne przedsiębiorstwa w sektorze MŚP zazwyczaj nie podejmują się przedsięwzięć polegających na analizie kompetencji: wiedzy, umiejętności oraz postaw i zachowań pracowników osiągających ponadprzeciętne rezultaty. Niewielu menedżerów projektów posługuje się odpowiednimi narzędziami i metodykami zarządzania projektami. Poziom dojrzałości projektowej poszczególnych przedsiębiorstw jest bardzo różny, a tym samym świadomość projektowa członków obserwowanych zespołów projektowych jest zróżnicowana, ale zdecydowanie kształtuje się na niskim poziomie.

\section{LITERATURA}

[1] Acedo F., Florin J., An entrepreneurial cognition perspective on the internationalization of SMEs, „Journal of International Entrepreneurship” 4/1 (2006), s. 49-67.

[2] Bernatt M., Spoteczna odpowiedzialność biznesu, Wymiar konstytucyjny i międzynarodowy, Wydawnictwo Naukowe Wydziału Zarządzania Uniwersytetu Warszawskiego, Warszawa 2009.

[3] Biznes, etyka, odpowiedzialność, red. W. Gasparski, PWN, Warszawa 2012.

[4] Bogdanienko J., Możliwości zwiększania innowacyjności małych i średnich firm w warunkach globalnej konkurencji, „Problemy Zarządzania” 2007/4, s. 74-94.

[5] Brilman J., Nowoczesne koncepcje i metody zarzadzania, PWE, Warszawa 2002.

[6] Clements J., Gido J., Successful project management, Cengage Learning, Mason 2009.

[7] Commission European, Putting small businesses first Europe is good for SMEs, SMEs are good for Europe, European Commission Publications Office, Luxembourg 2008.

[8] Dziekoński K., Zarzadzanie projektami w małych i średnich przedsiębiorstwach, „Ekonomia i Zarządzanie" 2010/4, s. 97-104.

[9] Floyd D., McManus J., The role of SMEs in improving the competitive position of the European Union, „European Business Review” 7/2 (2005), s. 144-150.

[10] Freeman R.E., Strategic Management: A stakeholders approach, Cambridge University Press, Cambridge 2010.

[11] Griffin R.W., Podstawy zarządzania organizacjami, PWN, Warszawa 1998.

[12] Hamilton A., Managing project for success, Thomas Telford Ltd., London 2001.

[13] Kaźmierczak M., Bezpieczeństwo i higiena pracy a rozwój koncepcji społecznej odpowiedzialności biznesu, „Zarządzanie i Ekonomia” 2009/5.

[14] Kisielnicki J., Zarządzanie projektami, Ludzie - procedury - wyniki, Wolters Kluwer Business, Warszawa 2011.

[15] Kurczewska A., Dyskusja nad pojęciem matego i średniego przedsiębiorstwa, Obecność problematyki sektora MSP w nauce ekonomii, „Ekonomista” 2009/2, s. 259-272.

[16] Low D., Chapman R., Inter-relationships between innovation and market orientation of SMEs, „Management Research News” 30/12 (2007), s. 878-891. 
[17] Murphy A., Ledwith A., Project management tools and techniques in high-technology SMEs, „Management Research News” 30/2 (2007), s. 153-166.

[18] Musiał-Urbańczyk A., Kompetencje kierownika projektu i możliwości ich ksztaltowania, Wydawnictwo Politechniki Śląskiej, Gliwice 2010.

[19] Newton R., The project manager: mastering the art of delivery, Pearson Education Limited, Harlow 2005.

[20] Nicholas J.M., Steyn H., Zarządzanie projektami, Wolters Kluwer Polska, Warszawa 2012.

[21] Noteboom B., Innovation and diffusion in small firm: theory and evidence, „Small Business Economics” 1994/6, s. 327-347.

[22] Owens J.D., Why do some UK SMEs still find the implementation of a new product development process problematic? An explanatory investigation, „Management Decision” 45/2 (2006), s. 235-251.

[23] Pisz I., Łapuńka I., Zarządzanie projektami w matych i średnich przedsiębiorstwach - wyniki badań, „Gospodarka Materiałowa i Logistyka” 2012/7, s. 16-22.

[24] Pisz I., Łapuńka I., The idea of operationalization of the conceptual model of project driven orders for small and medium-sized enterprises in condition of uncertainty, [w:] Innovations in management and production engineering, red. R. Knosala, PTZP, Opole 2012, s. 297-308.

[25] Raport o stanie sektora matych i średnich przedsiębiorstw w Polsce w latach 2007-2008, red. A. Żołnierski, Polska Agencja Rozwoju Przedsiębiorczości, Warszawa 2009.

[26] Raport o stanie sektora małych $i$ średnich przedsiębiorstw w Polsce, red. A. Brussa, A. Tarnawa, Polska Agencja Rozwoju Przedsiębiorczości, Warszawa 2011.

[27] Rudnicka A., CSR - doskonalenie relacji spolecznych $w$ firmie, Wolters Kluwer, Warszawa 2012.

[28] Salvato C., Lassini U., Wiklund J., Dynamics of external growth in SMEs: Process of model acquisition capabilities emergence, „Schmalebach Business Review” 59/3 (2007), s. 282-305.

[29] Spałek S., Krytyczne czynniki sukcesu w zarzadzaniu projektami, Wydawnictwo Politechniki Śląskiej, Gliwice 2004.

[30] Sroka H., Rozwój przedsiębiorstw sektora MSP w Polsce i znaczenie kredytu handlowego w ich funkcjonowaniu, [w:] red. C.F. Hales, Nauka dla gospodarki. Ekonomia i Zarzadzanie, Uniwersytet Rzeszowski, Rzeszów 2010, s. 201-209.

[31] Szpitter A.A., Innowacyjne podejście do zarządzania projektami, „Przegląd organizacji” 2012/1, s. $10-13$

[32] Ślęzak-Gładzik I., Corporate Social Responsibility (CSR) jako koncepcja porzadkująca relacje między biznesem a społeczeństwem, „Modern Management Review” XVIII/20 (2013), s. $113-125$.

[33] Turner J.R., Ledwith A., Kelly J., Project management in small to medium-sized enterprises. A comparison between firms by size and industry, „International Journal of Managing Projects in Business” 2/2 (2009), s. 282-296.

[34] Turner J.R., Ledwith A., Kelly J., Project management in small to medium-sized enterprises: Matching processes to nature of the firm, „International Journal of Project Management” 2010/28, s. 744-755.

[35] Von Dran G., Kappelman L., Prybutok V., Empowerment and the management of an organizational transformation project, „Project Management Journal” 27/1 (1996), s. 12-17.

[36] Walczak W., Orientacja na cele w zarzadzaniu projektami, „Master of Business Administration” 2009/4, s. 46-55.

[37] Woloński R., Rola wiedzy i innowacji $w$ rozwoju matych $i$ średnich przedsiębiorstw - przegląd dotychczasowych badań, „Problemy zarządzania” 2007/4, s. 128-155.

[38] Wong Z., Human factors in project management, Jossey-Bass, San Francisco 2007.

[39] Wyrozębski P., Modele kompetencji w zarządzaniu projektami, „e-mentor” 2009/2.

[40] „Zeszyty naukowe” 752, Uwarunkowania rynkowe rozwoju mikro, małych i średnich przedsiębiorstw. Mikrofirma 2013, „Ekonomiczne problemy usług” 2013/102. 
[41] Zięba K., Poszerzenie obszaru stosowania koncepcji CSR - prezentacja praktyki postępowania w tym zakresie, „Organizacja i Zarządzanie” 2/22 (2013), s. 153-165.

[42] Żmigrodzki M., Zarządzanie portfelem projektów malymi kroczkami, www.octigo.pl (dostęp: 23.04.2012)

[43] http://biznes.pl/wiadomosci/raporty/spojnosc-i-mierzenie-efektywnosci-kluczami-dosukc,5607953,1,5585484,510,news-detal.html (dostęp: 10.03.2014).

\section{BUILDING THE COMPETITIVENESS AND THE RELATIONS DEVELOPMENT OF SMALL AND MEDIUM SIZED-ENTERPRISES WITH SOCIO-ECONOMIC ENVIRONMENT}

Introduction to the enterprise concept of corporate social responsibility CSR is particularly important in the case of companies belonging to the sector of small and medium-sized enterprises (SMEs sector). In the SMEs sector in recent times there has been a significant change in the way of doing business. In the manufacturing system stands out more and more tasks by the tasks of a unique, so-called projects driven order. The transformation of production in order to project approach (project driven order) requires a lot of knowledge, experience, tools, new methods and techniques to achieve or surpass the needs and expectations of customers. It is assumed that in the context of the implementation of CSR policies in the enterprise, including in the SMEs sector, managerial, social and personal competence will play a vital role. The aim of the study is to present the concept of research on the investigation and an analysis of managerial competence, social and personal of project managers, and the projects driven order in the context of the current policy of CSR in the SMEs sector. The basic premises of research, the research problem was formulated. The background of the research was presented. The main aims, objectives, hypotheses and tasks were formulated.

Keywords: CSR, Corporate Social Responsibility, competition, project driven order, project, sector of small and medium-sized enterprises.

\section{DOI: $10.7862 /$ rz.2014.mmr.10}

Tekst złożono w redakcji: marzec 2014

Przyjęto do druku: marzec 2014 